\title{
Efficient solution-processable electrophosphorescence for trifluoromethylpyridinto iridium with sensitizing agent
}

\author{
Wenguan Zhang ${ }^{1, a}$, Lian Qin ${ }^{1, b}$, Shengmin Zhao ${ }^{1, c}$ \\ ${ }^{1}$ Lab of Printing \& Packaging Material and Technology-Beijing Area Major Laboratory, \\ Beijing Institute of Graphic Communication, Beijing 102600, P. R. China \\ a'wenguanzhang@sina.com, ${ }^{b}$ qinlian@bigc.edu.cn, ${ }^{\mathrm{C}}$ zhaoshengmin@bigc.edu.cn
}

Keywords: Iridium complex; Trifluoromethyl; Solution-processable; Sensitizing agent; Electrophosphorescent device.

\begin{abstract}
The devices based on dopant bis[2-(4-(2'-ethylhexyloxy)phenyl)-5-trifluoromethylpyridinto- $\left.\mathrm{C}^{3}, \mathrm{~N}\right]$ iridium (acetylacetonate) $\left(\mathrm{EHO}-5 \mathrm{CF}_{3}-\mathrm{ppy}\right)_{2} \operatorname{Ir}(\mathrm{acac})$ were fabricated by spin-casting and depositing technique. The dopant was chosen at the different concentration (2 and 8 wt. \%) and doped in host materials (single PVK or PVK blending with PBD), furthermore, $\operatorname{Ir}\left(\right.$ ppy) ${ }_{3}$ as the sensitizing agent was added to improve luminous efficiency of the devices. The four devices emitted EL peaks at about $540 \mathrm{~nm}$ from $\left(\mathrm{EHO}-5 \mathrm{CF}_{3}-\mathrm{ppy}\right)_{2} \operatorname{Ir}(\mathrm{acac})$. With the increasing of doping concentration the luminances raised. At the same concentration of $8 \%$, device containing host PVK blending with PBD exhibited much higher luminance than one containing host PVK, while device with the sensitizing agent $\operatorname{Ir}(\mathrm{ppy})_{3}$ displayed unexpectedly high brightness. All devices emitted strong yellow-green electro- phosphorescence, which showed that the transport of electron and hole was balanced and that energy transfer from the host and the sensitizing agent to the guest complex was efficient.
\end{abstract}

\section{Introduction}

Utilizing singlet and triplet excitons, phosphorescent organic light-emitting diodes (OLEDs) have proven to be more efficient [1]. The cyclometallated Ir complexes were superior to the other metal complexes because of the relatively short lifetime of their triplet state. The ligands of complexes were changed to extend synthesis and to tune emission color [2]. Trifluoromethyl and dendritic ethylhexyloxy group were introduced into iridium ligand to tune luminescent color, to prevent luminescence quenching and to improve the solution-processable property. A yellow-green solution-processable phosphorescent material, bis[2-(4-(2'-ethylhexyloxy)phenyl)-5-trifluoromethylpyridinto- $\left.\mathrm{C}^{3}, \mathrm{~N}\right]$ iridium (acetylacetonate) $\left(\mathrm{EHO}-5 \mathrm{CF}_{3}-\mathrm{ppy}\right)_{2} \operatorname{Ir}(\mathrm{acac})$, was synthesized and the electroluminescent (EL) device was discussed [3]. In this work, the devices including (EHO-5 $\mathrm{CF}_{3}$-ppy $)_{2} \operatorname{Ir}(\mathrm{acac})$ at the different doping concentration and host materials as well as in the presence of sensitizing agent $\operatorname{Ir}(\mathrm{ppy})_{3}$ were fabricated by spin-casting and depositing method. All devices exhibited strong yellow-green electrophosphorescence. The current density, voltage, luminance, EL spectra, and Commission International de L'Eclairage (CIE) coordinates of the devices were investigated.

\section{Experimental}

Molecular structure. Dopant (EHO-5CF - ppy $)_{2} \operatorname{Ir}(\mathrm{acac})$ [3] was seen in Fig. 1.

Instruments. UV-vis absorption and photoluminescence (PL) spectra were tested on a Shimadzu UV-2501 PC and Perkin Elmer LS-55 luminescence spectrometer. Cyclic Voltammetry (CV) was measured by using Zahner Zennium electrochemical workstation.

Device fabrications and testing. The poly(3,4-ethylenedioxythiophene): poly(styrenesulfonic acid) (PEDOT: PSS) as a hole-injecting layer was spin-cast onto indium tin oxide (ITO) surface. The emitting layers: $\left(\mathrm{EHO}-5 \mathrm{CF}_{3}-\mathrm{ppy}\right)_{2} \operatorname{Ir}(\mathrm{acac})(2 \mathrm{wt} \%$ for Device $\mathrm{A} 1,8 \mathrm{wt} \%$ for A2) was doped in poly(vinylcarbazole) (PVK) blending with 2-tert-butylphenyl-5-biphenyl-1,3,4-oxadiazol (PBD) (40 
wt \%). Device A3: both (EHO-5CF 3 -ppy $)_{2} \operatorname{Ir}(\mathrm{acac})(8 \mathrm{wt} \%)$ and sensitizing agent $\operatorname{Ir}(\mathrm{ppy})_{3}(1 \mathrm{wt} \%)$ were doped in PVK and PBD. Device A4: (EHO-5CF - ppy) $)_{2} \operatorname{Ir}(\mathrm{acac})(8 \mathrm{wt} \%)$ was doped in single PVK. The four groups of emitting mixture in chloroform were spun onto PEDOT:PSS layer [4]. 1,3,5-Tris ( $N$-phenylbenzimidazol-2-yl)benzene (TPBi) as an electron-transporting layer and a complex cathode $\mathrm{LiF} / \mathrm{Al}$ were deposited on emitting layer in turn by sequential vacuum thermal evaporation. Four electroluminescent devices were fabricated as follows: Devices A1 and A2 ITO/PEDOT:PSS/PVK:PBD:(EHO-5CF - -ppy) $2 \operatorname{Ir}(\mathrm{acac})$ (2 and $8 \mathrm{wt} \%) / \mathrm{TPBi} / \mathrm{LiF} / \mathrm{Al}$, Device A3 ITO/PEDOT:PSS/PVK:PBD:(EHO-5CF - ppy) $2 \operatorname{Ir}(\mathrm{acac})(8 \mathrm{wt} \%): \operatorname{Ir}(\mathrm{ppy})_{3}(1 \mathrm{wt} \%) / \mathrm{TPBi} / \mathrm{LiF} / \mathrm{Al}$, and Device A4 ITO/PEDOT:PSS/PVK:(EHO-5CF - -ppy) $)_{2} \operatorname{Ir}(\mathrm{acac})(8 \mathrm{wt} \%) / \mathrm{TPBi} / \mathrm{LiF} / \mathrm{Al}$ were fabricated.

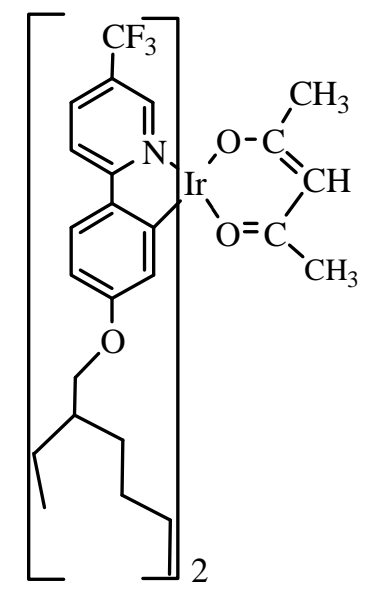

$\left(\mathrm{EHO}-5 \mathrm{CF}_{3}-\mathrm{ppy}\right)_{2} \operatorname{Ir}(\mathrm{acac})$

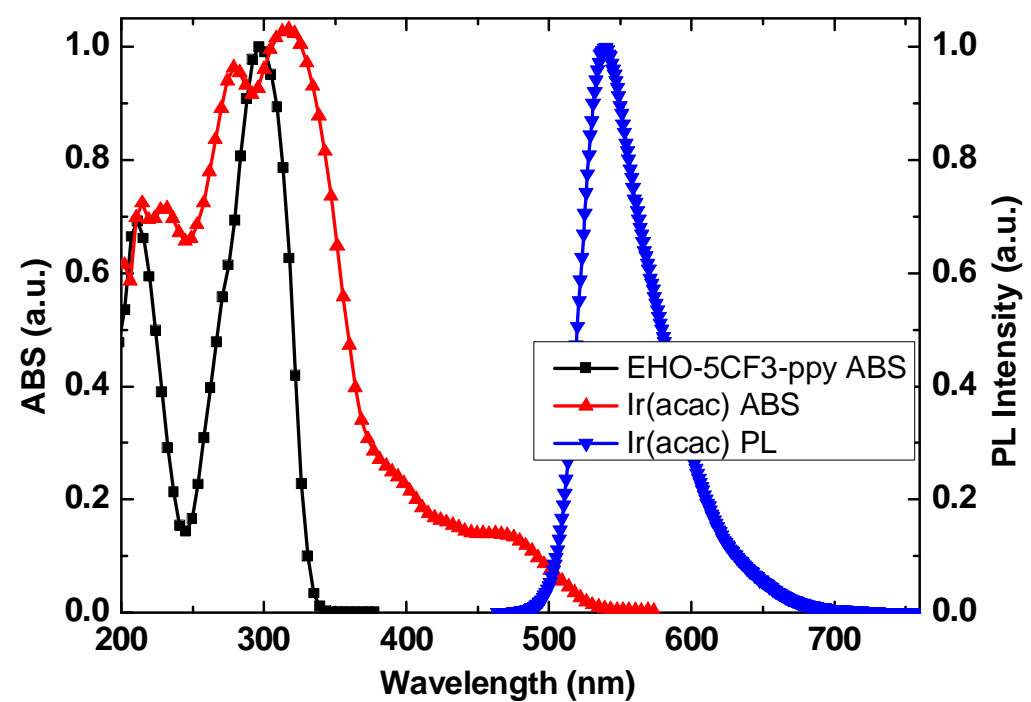

Fig. 2 UV-vis absorption and emission spectra

Fig. 1 Structure of $\left(\mathrm{EHO}-5 \mathrm{CF}_{3}-\mathrm{ppy}\right)_{2} \mathrm{Ir}(\mathrm{acac})$

EL spectra and CIE coordinates were performed with SpectroScan PR 655 photometer (Photo Research). The luminance-current-voltage characteristics were carried out by a computer controlled Keithley 2420 source meter unit with Minolta LS 110 luminescence meter. The devices were measured at room temperature under dark and ambient atmosphere.

\section{Results and discussions}

Photophysical properties. The UV-vis absorption and PL spectra of (EHO-5CF $3-p p y)_{2} \operatorname{Ir}(\mathrm{acac})$ in THF were shown in Fig. 2. The main peak of UV absorption at $318 \mathrm{~nm}$ exhibited bathochromic effect compared with one of ligand $\mathrm{EHO}-5 \mathrm{CF}_{3}-\mathrm{ppy}$ at $297 \mathrm{~nm}$. The main PL peak of $\left(\mathrm{EHO}-5 \mathrm{CF}_{3}-\right.$ ppy) ${ }_{2} \operatorname{Ir}($ acac) was at $540 \mathrm{~nm}$.

Electrochemical properties. The highest occupied molecular orbit (HOMO) and the lowest unoccupied molecular orbit (LUMO) energy levels of (EHO-5CF $3-p p y)_{2} \operatorname{Ir}(\mathrm{acac})$ were investigated by $\mathrm{CV}$ in anhydrous dichloromethane in the presence of tetra- $n$-butylammoniumhexafluorophosphate $\left(\mathrm{TBAPF}_{6}\right)$ $(0.1 \mathrm{M})$ as a supporting electrolyte. $\mathrm{An} \mathrm{Hg} / \mathrm{Hg}^{+}$electrode acted as a reference electrode, a platinum wire as a counter electrode, a glass carbon electrode as a working electrode. Ferrocene served as a reference. The scan rate was $50 \mathrm{mV} / \mathrm{s}$ [5]. The redox curves were found (ferrocene in the inset) in Fig. 3. The onset oxidation potential of (EHO-5CF - ppy $)_{2} \operatorname{Ir}(\mathrm{acac})$ was $0.94 \mathrm{eV}, \mathrm{HOMO}$ was calculated to be $-5.38 \mathrm{eV}$. The UV-vis absorption spectrum edge was at $541 \mathrm{~nm}$, the energy gap was estimated to be $2.29 \mathrm{eV}$. LUMO was calculated to be $-3.09 \mathrm{eV}$. 


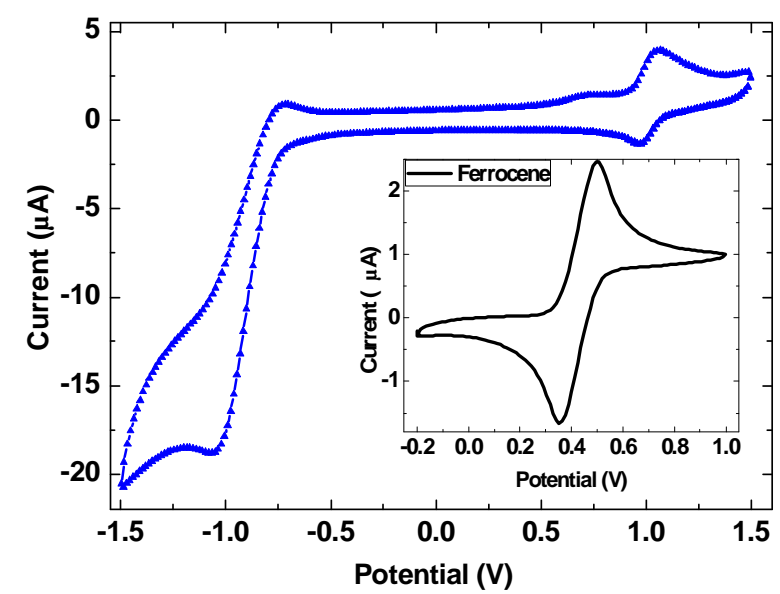

Fig. 3 The CV curves

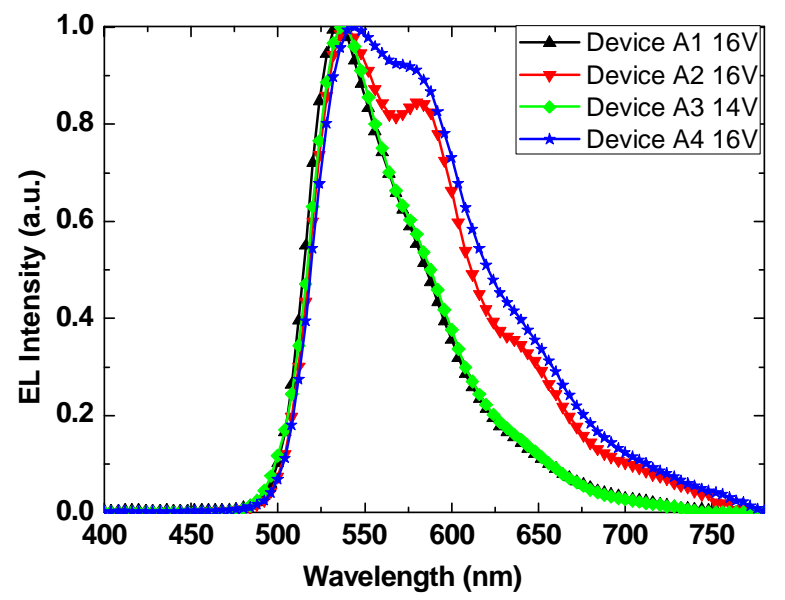

Fig. 4 EL spectra

EL properties. EL spectra appeared in Fig. 4. Energy level diagrams and device structure were shown in Fig. 5. When PVK blending with PBD were used as the host materials, Devices A1 (2 wt $\%$ ) and A2 (8 wt $\%)$ showed EL main peaks both at $540 \mathrm{~nm}$. With the increasing of doping concentrations from $2 \%$ to $8 \%$, EL emission changed from no obvious shoulder peak to a shoulder peak at $581 \mathrm{~nm}$. EL peak for Device A3 with sensitizing agent $\operatorname{Ir}(\mathrm{ppy})_{3}(1 \mathrm{wt} \%)$ was at $536 \mathrm{~nm}$ and no obvious shoulder peak existed. EL emission from $\operatorname{Ir}(\mathrm{ppy})_{3}$ did not appeared at $512 \mathrm{~nm}$ in EL spectrum for A3, this revealed energy transfer from $\operatorname{Ir}(\mathrm{ppy})_{3}$ to $\left(\mathrm{EHO}-5 \mathrm{CF}_{3}-\mathrm{ppy}\right)_{2} \operatorname{Ir}(\mathrm{acac})$. Device A4 emitted a main peak at $544 \mathrm{~nm}$ and a should peak at $580 \mathrm{~nm}$. When only PVK in Device A4 (8\%) was used as the host material, the EL main wavelength had no obvious shift, but the relative intensity of their shoulder peak at $580 \mathrm{~nm}$ was higher than that in PVK blending with PBD for Device A2 (when the main EL peaks were normalized). The EL spectra of four devices showed the recombination of holes and electrons in the emitting layer, and EL emissions were in accordance with the PL emission for $(\text { EHO-5CF }- \text { ppy })_{2} \operatorname{Ir}(\mathrm{acac})$ at $540 \mathrm{~nm}$.

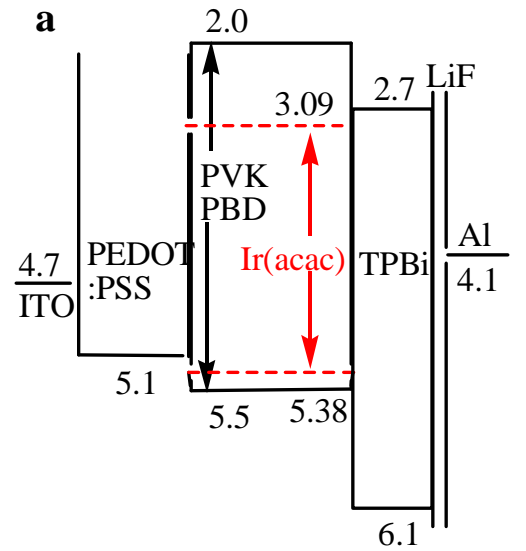

A1 $\operatorname{Ir}(\mathrm{acac})(2 \%)$, A2 $\operatorname{Ir}(\mathrm{acac})(8 \%)$

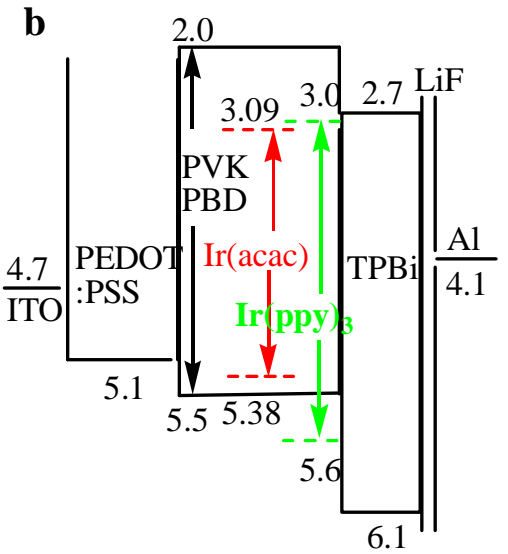

A3 $\operatorname{Ir}($ acac $)(8 \%)+\operatorname{Ir}(\text { ppy })_{3}(1 \%)$

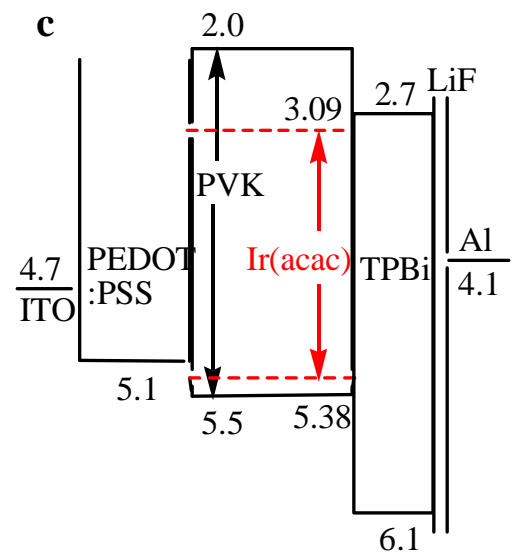

A4 $\operatorname{Ir}(\mathrm{acac})(8 \%)$

Fig. 5 Energy level diagrams and device structure $\left(\left(\mathrm{EHO}-5 \mathrm{CF}_{3}-\mathrm{ppy}\right)_{2} \operatorname{Ir}(\mathrm{acac})\right.$ abbreviated as $\left.\operatorname{Ir}(\mathrm{acac})\right)$

The absence of emission from PVK or PVK blending with PBD as the host material in these devices indicated that the transport of electron and hole was balanced and energy transfer from the host to the guest complex was efficient [6]. CIE coordinates of four devices were listed in Table 1. With the change of the doping concentration and host materials as well as the presence of sensitizing agent $\operatorname{Ir}(\mathrm{ppy})_{3}$, CIE coordinates were located at the yellow-green colors. Four devices exhibited strong yellow-green electrophosphorescence. 
Table 1 CIE coordinates of devices at the bias voltage

\begin{tabular}{|c|c|c|c|c|}
\hline Device & $\mathrm{A} 1(16 \mathrm{~V})$ & $\mathrm{A} 2(16 \mathrm{~V})$ & $\mathrm{A} 3(14 \mathrm{~V})$ & $\mathrm{A} 4(16 \mathrm{~V})$ \\
\hline CIE x & 0.409 & 0.429 & 0.386 & 0.446 \\
$\mathrm{y}$ & 0.567 & 0.556 & 0.592 & 0.539 \\
\hline
\end{tabular}

Current density and luminance curves were showed in Fig. 6. At a given current density of 20 $\mathrm{mA} / \mathrm{cm}^{2}$, the corresponding bias voltages were 16.0 for $\mathrm{A} 1,11.9$ for $\mathrm{A} 2,13.7$ for $\mathrm{A} 3$, and $16.1 \mathrm{~V}$ for $\mathrm{A} 4$, respectively. Turn-on voltages (the voltage when the luminance reached $1 \mathrm{~cd} / \mathrm{m}^{2}$ ) were $9.1 \mathrm{~V}$ for $\mathrm{A} 1,7.1 \mathrm{~V}$ for A2, 6.3 V for A3, and 8.6 V for A4, respectively. Maximum luminances were found to be $12302 \mathrm{~cd} / \mathrm{m}^{2}$ for A1 $(23 \mathrm{~V}), 15703 \mathrm{~cd} / \mathrm{m}^{2}$ for A2 $(17 \mathrm{~V}), 48102 \mathrm{~cd} / \mathrm{m}^{2}$ for A3 $(18 \mathrm{~V})$, and $2948 \mathrm{~cd} / \mathrm{m}^{2}$ for A4 $(21 \mathrm{~V})$, respectively. With the increasing of doping concentration in PVK with PBD, the turn-on voltages reduced and luminances were enhanced at the given voltage. At the same concentration of $8 \%$, Device for host PVK with PBD showed lower turn-on voltage and much higher luminance than Device for host only PVK. Device A3 with the sensitizing agent $\operatorname{Ir}(\mathrm{ppy})_{3}$ (host PVK with PBD) displayed much higher luminance than Device A1 (host PVK with PBD), Device A2 (host PVK with PBD), and Device A4 (host only PVK). In conclusion, the results indicated that the devices had excellent luminance and stability, and that Ir complex had the promising application for making yellow-green or white OLEDs.
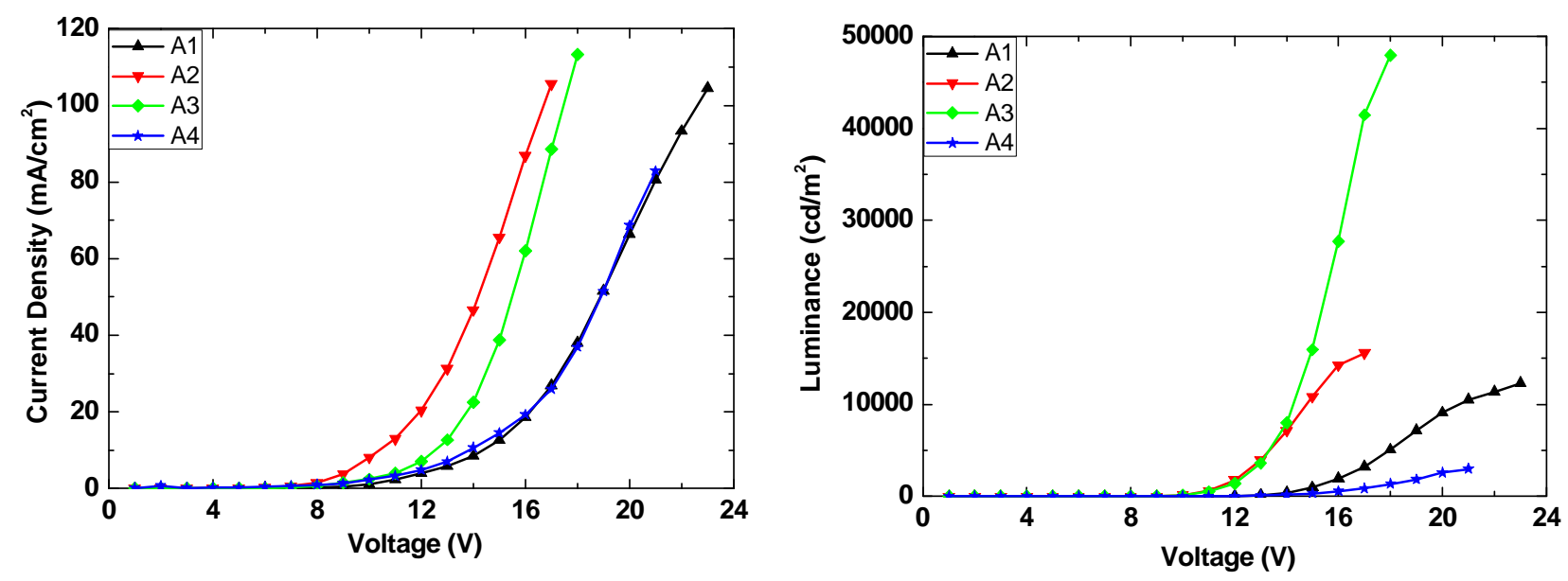

Fig. 6 Current density (left) and luminance curves (right)

\section{Conclusions}

Four yellow-green devices based on $\left(\mathrm{EHO}-5 \mathrm{CF}_{3}-\mathrm{ppy}\right)_{2} \operatorname{Ir}(\mathrm{acac})$ were fabricated by spin-casting and depositing method, EL emissions were influenced by the doping concentrations, host materials and sensitizing agent $\operatorname{Ir}(\text { ppy })_{3}$. The four devices showed $\mathrm{EL}$ peaks at about $540 \mathrm{~nm}$ from (EHO-5 $\mathrm{CF}_{3}$-ppy $)_{2} \operatorname{Ir}$ (acac). Luminances were enhanced with the increasing of doping concentration at the given voltage. Device of host PVK blending with PBD showed much higher luminance than device of host PVK at the same concentration of $8 \%$, while device with the sensitizing agent $\operatorname{Ir}(\mathrm{ppy})_{3}$ exhibited incredibly high brightness. All devices exhibited strong yellow-green electrophosphorescence, which indicated that the transport of electron and hole was balanced and that energy transfer from host and $\operatorname{Ir}(\mathrm{ppy})_{3}$ to the guest complex was efficient. $\left(\mathrm{EHO}-5 \mathrm{CF}_{3}-\mathrm{ppy}\right)_{2} \operatorname{Ir}(\mathrm{acac})$ was an excellent emitter for potential application in yellow-green or white OLED.

\section{Acknowledgments}

This work was funded by the Beijing Commission of Education Grants (KM201310015004). 


\section{References}

[1] C. Adachi, M.A. Baldo, M.E. Thompson, S.R. Forrest, Nearly $100 \%$ internal phosphorescence efficiency in an organic light-emitting device, J. Appl. Phys. 90 (2001) 5048-5051.

[2] S. Lamansky, P. Djuroch, D. Murphy, F. Abdel-Razzaq, R. Kwong, I. Tsyba, M. Bortz, B. Mui, R. Bau, M.E. Thompson, Synthesis and characterization of phosphorescent cyclometalated Iridium complexes, Inorg. Chem. 40 (2001) 1704-1711.

[3] W.G. Zhang, Z.Q. He, Y.S. Wang, S.M. Zhao, Solution-processable phosphorescence based on iridium-cored small molecules with the trifluoromethyl group, Opt. Mater. 42 (2015) 137-143.

[4] X. Gong, J.C. Ostrowski, D. Moses, G.C. Bazan, A.J. Heeger, Electrophosphorescence from a polymer guest-host system with an iridium complex as guest: Förster energy transfer and charge trapping, Adv. Funct. Mater. 13 (2003) 439-444.

[5] W.G. Zhang, Z.Q. He, Y.S. Wang, S.M. Zhao, Non-doped red-green-blue electroluminescent devices based on fluorenyl and phenanthryl phenylamino derivatives, Thin Solid Films 562 (2014) 299-306.

[6] W.G. Zhang, Y.S. Wang, Z.Q. He, L.P. Mu, Y. Zou, C. J. Liang, S.M. Zhao, Efficient electrophosphorescence based on 2-(9,9-diethylfluoren-2-yl)-5-trifluoromethylpyridine iridium complexes, Synth. Met. 160 (2010) 354-360. 